Original Research Paper

\title{
The Effects of Seasonal Variations on Typha capensis and Heliconia psittacorum in the Remediation of Heavy Metals from Soil and Water
}

\author{
${ }^{1}$ Wiafe Samuel, ${ }^{2}$ Buamah Richard and ${ }^{3}$ Owusu Michael \\ ${ }^{1}$ Regional Water and Environmental Sanitation Centre, Kumasi, Ghana \\ ${ }^{2}$ Department of Civil Engineering, KNUST, Kumasi, Ghana \\ ${ }^{3}$ Regional Water and Environmental Sanitation Centre, Kumasi, Ghana
}

\author{
Article history \\ Received: $19-10-2018$ \\ Revised: 27-12-2018 \\ Accepted: 23-01-2019 \\ Corresponding Author: \\ Wiafe Samuel \\ Regional Water and \\ Environmental Sanitation \\ Centre, Kumasi, Ghana \\ Email: samwafy@yahoo.co.uk
}

\begin{abstract}
Different plant species have been used in the remediation of different heavy metals. The performance of a macrophyte to remediate heavy metals may be dependent on a lot of factors which may include water chemistry, metal solubilityand temperature. The objective of this research was to ascertain the effects of seasonal variations on the remediation of heavy metals. To this end,two macrophytes: Typha capensis and Heliconia psittacorum were employed in the remediation of Arsenic, Lead, Mercury and Cadmium under two seasons (dry and wet). The plants were dosed withknown concentrations of the heavy metals under different temperature and humidity for a period of forty days. The plant samples were subjected to heavy metal analysis by Atomic absorption spectroscopy. The exposure of the heavy metals uptake under seasonal variations showed that, the remediation of the four selected heavy metals by the two plants were very effective during the dry weather conditions than that of the wet weather conditions.
\end{abstract}

Keywords: Seasonal, Remediation, Heavy Metals, Macrophytes

\section{Introduction}

Submerged macrophytes may be useful in reducing heavy metal concentrations in soil/water; they have the ability to take up heavy metals directly from water and accumulate them in their shoots. A lot of macrophytes have been used in the remediation of different heavy metals from water and soil. However, the conditions that may affect the macrophytes ability to absorb the heavy metals from soil/water needs to be researched into. In a tropical climate like that of Ghana, the temperature and humidity varies with the season and that also affects the growth of plants most especially aquatic macrophytes. The seasonal variations in temperature and humidity also affects water bodies which serves as one of the vital sources of requirements plants needs to grow. The water temperature may exceed $30^{\circ} \mathrm{C}$ in the dry season and can decrease to as low as $21^{\circ} \mathrm{C}$ or below in the wet season.Water temperature may influence water chemistry, metal solubility and metal uptake by plants and plant growth.The thrust of this research was to ascertain the effects of seasonalvariations on the remediation of heavy metals (Arsenic, Lead, Mercury and Cadmium) by Typha capensis and Heliconia psittacorum.

According to Zumdahl (1992), seasonal variation in water temperature has no direct effect on the solubility of metal in water. However, cool water contains more dissolved oxygen than warm water. Thus, metal concentration in the interstitial water of the sediment may decrease with decreasing temperature, as more metals are bound to sediment colloids at high rather than low redox potentials (Forstner, 1979). In addition, temperature has a profound effect on plant growth rates and higher temperatures will thus result in greater biomass production and distribution of submerged macrophyte communities (Marschner, 1995; Rooney and Kalff, 2000). Several studies of terrestrial plants grown at high temperatures found higher uptakes of $\mathrm{Zn}, \mathrm{Pb}, \mathrm{Ag}$, $\mathrm{Cr}, \mathrm{Sb}$ and $\mathrm{Cd}$ than was the case with plants grown at low root temperatures (Hooda and Alloway, 1993; Macek et al., 1994; Baghour et al., 2001; Albrecht et al., 2002). Therefore, a general increase of metal uptake with increasing temperature seems likely.Changes in temperature further change the composition of the plasma membrane lipids (Lynch and Steponkus, 1987).

\section{Materials and Methods}

\section{Study Area}

The study was conducted in a piloted wetland in Sunyani, Ghana (Fig. 1). Thestudy area lies between 
latitude $7^{\circ} 20^{\prime} 5.79^{\prime \prime} \mathrm{N}$ and longitude of $2^{\circ} 18^{\prime} 44.29^{\prime \prime} \mathrm{W}$. The first rainy season starts from May to July and the second from September to November. The dry (harmattan) season occurs between December and April and is associated with drought condition (Boadi et al., 2013). The annual rainfall of the Municipality averages between $25-330 \mathrm{~mm}$. The daily temperature ranges from $23^{\circ} \mathrm{C}-32^{\circ} \mathrm{C}$ with minimum monthly temperature of $26^{\circ} \mathrm{C}$ and maximum temperature of $30^{\circ} \mathrm{C}$ recorded in March and April. The average humidity in the area is 75-80\% (Boadi et al., 2013).

\section{Sampling and Heavy Metal Analysis}

Two macrophytes:Typha capensis and Heliconia psittacorum were used in the uptake of Mercury, Arsenic, Cadmium and Lead under varying Temperature and Humidity. The plants seedlings were obtained from the horticulture department of the Kwame Nkrumah University of Science and Technology, Kumasi, Ghana. The seedlings were two weeks old and were transplanted into the pots. Table 1 shows the soil characteristics used in the growth of the plants. Eight plants were grown in each of the containers. The two macrophytes were not planted together in one container but each of them were confined to a particular container. A total of eighteen (18) containers (pots) with dimensions: $0.26 \mathrm{~m}$ length, $0.14 \mathrm{~m}$ width and $0.24 \mathrm{~m}$ depth filed with $5 \mathrm{~kg}$ of garden soil (with known composition) Table 1, were used to grow the plants. The study was conducted in two main seasons in Ghana (dry and wet seasons). The wet season spanned from June 20, 2017 to July 31, 2017. The dry season also spanned from November 6, 2017 to December 22, 2018. The daily mean temperature, relative humidity and evaporation recorded for the dry climate conditions were $31.43^{\circ} \mathrm{C}, 62.18 \%$ and 355.29 $\mathrm{mm} /$ day. On the other hand, the daily mean temperature, relative humidity and evaporation recorded for the dry climate conditions were $26.40^{\circ} \mathrm{C}, 84.48 \%$ and 73.14 $\mathrm{mm} /$ day. The plants weredosed with standard heavy metal simulated solutions with 1 litre of water to mimic the concentrations that prevail in typical illegal gold mining catchment. The water used in the simulated solution had a temperature of $15^{\circ} \mathrm{C}$ and a $\mathrm{pH}$ of 6.5 . The macrophytes were dosed with heavy metal solution containing $5 \mathrm{pm}$ arsenic, $5 \mathrm{pm}$ mercury and $10 \mathrm{pm}$ lead and cadmium. The irrigation was conducted every three days in a one-off regime. The entire experiment was conducted over a period of 40 days. In the control experimental batches, deionized water was used. The initial soil heavy metal concentration was analyzed. After 10 days of cultivation, two out of the eight plants in each of the pots were harvested and the amount of heavy metals uptake by the plants determined. This process was repeated after the 20, 30 and 40 days of cultivation. Duplicate samplings were collected for each of the harvested days for each of the plants. During each harvesting episode, two plants from the control set was also harvested and analysed for heavy metals.
Table 1: Physico- chemical analysis of soil used in the plants' growth

\begin{tabular}{lr}
\hline Soil characteristics & Value \\
\hline $\mathrm{pH}$ & 7.53 \\
Conductivity $(\mu \mathrm{S} / \mathrm{m})$ & 42.20 \\
Organic matter $(\%)$ & 28.51 \\
Organic carbon $(\%)$ & 16.54 \\
\%sand & 88.76 \\
\%clay & 4.32 \\
\%silt & 6.92 \\
\hline
\end{tabular}

The soil has a $\mathrm{pH}$ of 7.53, showing neutral conditions in the soil. The presence of ions in the soil was also determined by the electrical conductivity which gave a reading of $42.2 \mu \mathrm{s} / \mathrm{m}$. The presence of Organic matter and Organic carbon $(28.51 \%$ and $16.54 \%)$ respectively indicates that the soil could support the growth of the macrophytes. Therefore, no plant growth enhancement like fertilizers or organic manure was added. Textural classification revealed the soil to be a sandy soil containing $88.76 \%$ of sand, $4.2 \%$ silt and $6.9 \%$ clay (Table 1 ).

\section{Heavy Metal Analysis}

The harvested plants were collected in clean plastic bags. After collection, samples were carried to the University of Ghana Ecological laboratory for heavy metal analysis usingAtomic absorption spectroscopy.

\section{Results and Discussion}

\section{Arsenic Uptake by T. capensis and H. psittacorum}

The uptake of Arsenic in both dry and wet seasonal conditions by $T$. capensis and $H$. psittacorum are indicated in Fig. 2. For Typha capensis, there was an incremental uptake in both the roots and shoots. The uptake levels in the dry season was almost as twice that which occurred in the wet season (Fig. 2 and 3). In both seasons, the roots recorded high Arsenic accumulation than the shoots, giving a Translocation Factor (shoot/root ratio) $(\mathrm{TF})<1$, (Tables 4 and 5). Again, in the dry season, the highest accumulation occurred on the 40th day of harvest with the least accumulation occurring on the 10th day of harvest. Statistically, there was no significant difference between the dry season uptake and that of the wet season ( $>0.05)$, (Tables 2 and 3). However, there was significant differences in terms of the root uptake and TF for both seasons $(\mathrm{p}<0.05)$, (Table 2-5). In relation to the remediation of As by $H$. psittacorum, there was high uptake by the roots within the first 10 days which declined to the 30th day before increasing again within the last 10 days (40th day harvest). This trend of uptake was observed for both seasons. However, the uptake increased with exposure time and this implied that the rate of uptake was dependent on the number of days themacrophytes were exposed to the heavy metals. 


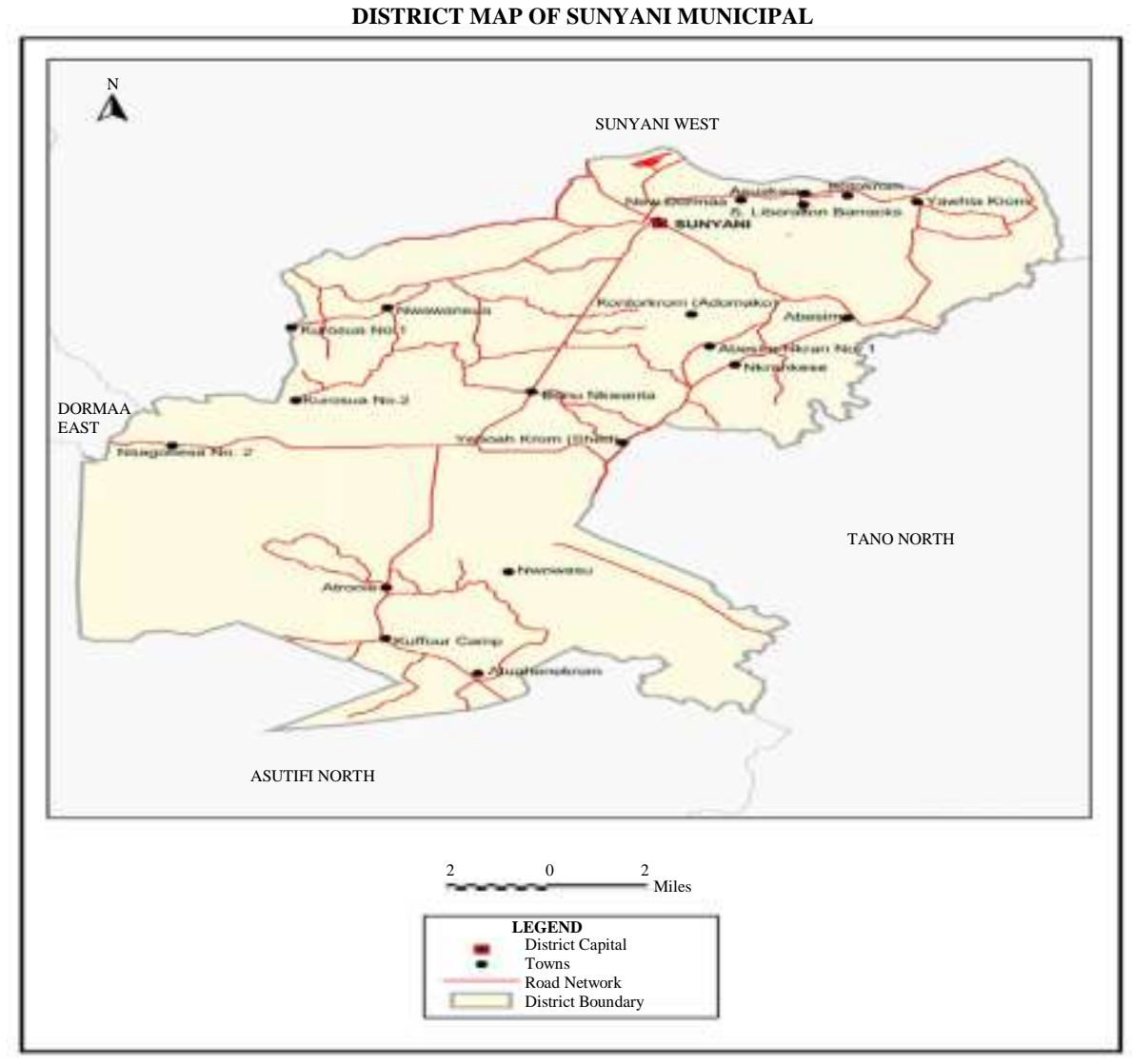

Fig. 1: Map showing the study area

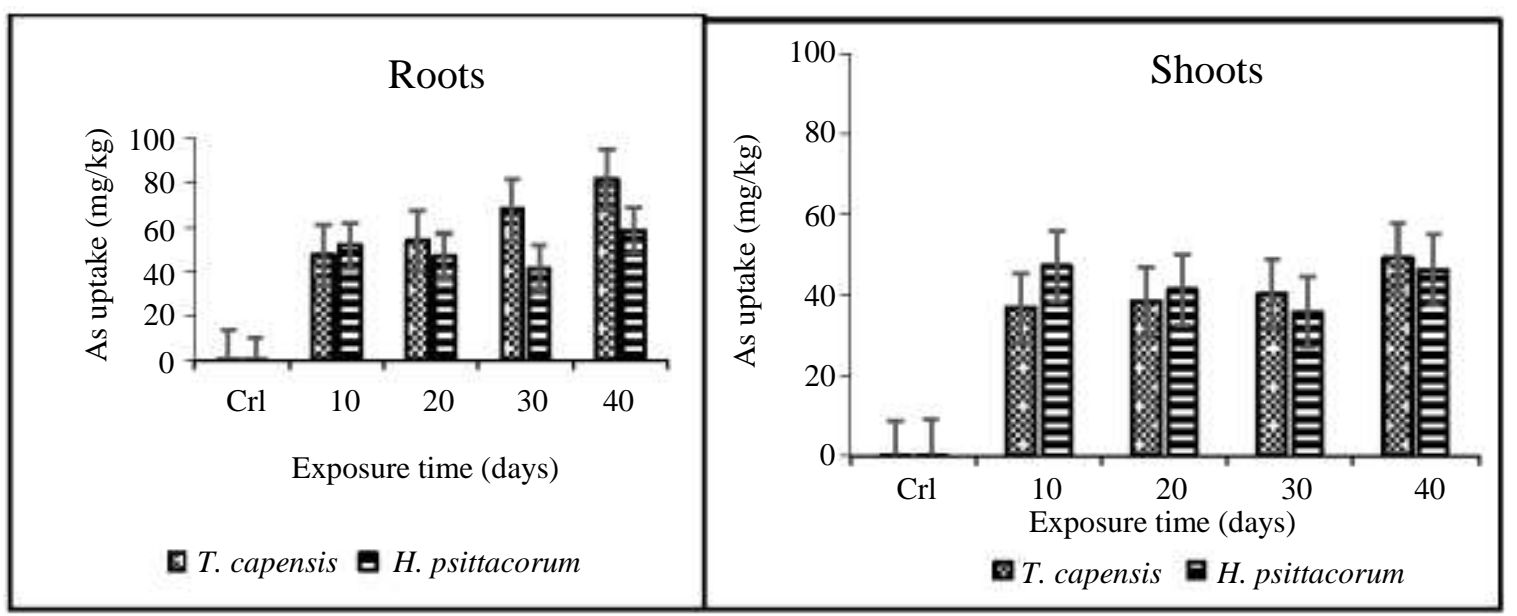

Fig. 2: Performance of T. capensis and H. psittacorum in Dry weather condition

The rate of the heavy metals' accumulation in the shoots of the macrophytes' recorded a higher levels during the dry season than the wet season. In the dry season, the TF of $H$. psittacorum was $>1$, (Table 5) whereas TF was less than one in the wet season. High TF values indicates a high rate of translocation of Arsenic from the roots of psittacorum to its shoots. Statistically there was no significant differences for the Arsenic uptake by $H$. psittacorum in both seasons. There was also no significant differences between the uptake by roots and shoots. Nonetheless, the TF showed significant difference for $H$. psittacorum (Table 5). 


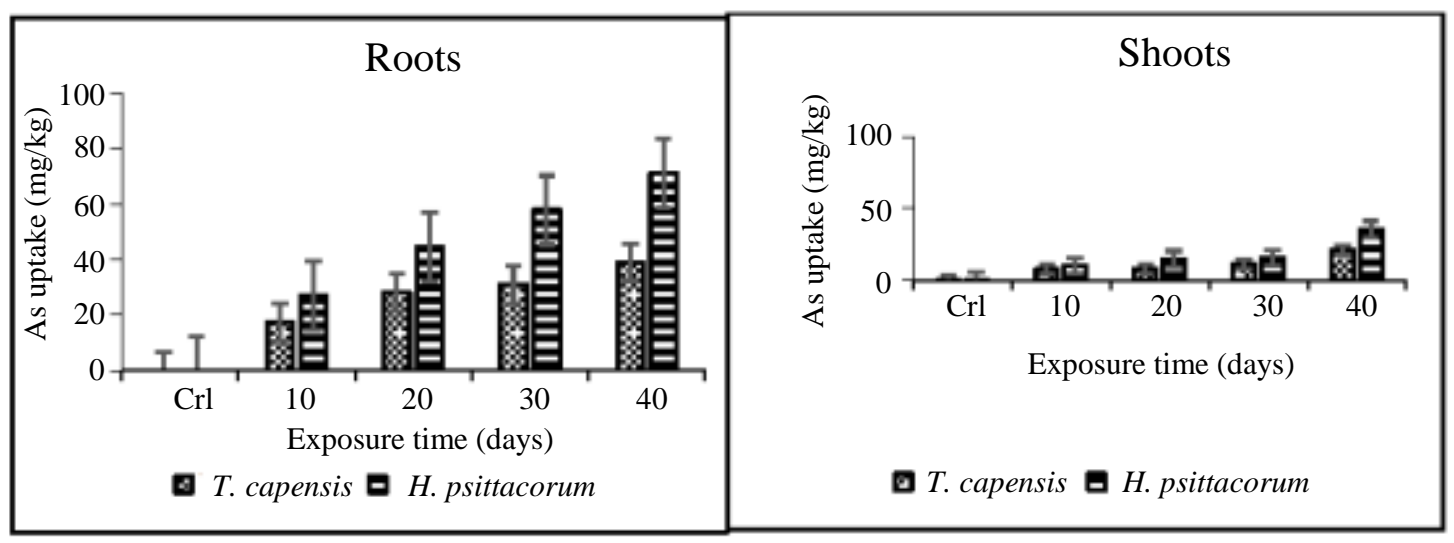

Fig. 3: Performance of $T$. capensis and $H$. psittacorumin Wet weather conditions

\section{Comparative Performance of Arsenic Removal by T. capensis and H. psittacorum}

The Arsenic uptake by both macrophytes were higher during the dry season than the wet season. This was observed because, usually dry seasons are characterized by high temperature and low humidity. This further leads to high transpiration which affected the uptake of Arsenic from the soil. Among the two macrophytes, $T$. capensis showed the greater potential for Arsenic removal (Fig. 2). However, in the case of Arsenic translocation, there were higher translocation from root to shoot of $H$. psittacorum than $T$. capensis. This observation can be attributed to the morphology of the macrophytes. $H$. psittacorum has broader leaves as compared to $T$. capensis with conspicuously thin leaves. The broader leaves presented large surface area for transpiration and lead to the high TF values in the Heliconia species. The above observation occurred for the rest of the heavy metals studied in this research work.

The results of this study has shown that $T$. capensis and $H$. psittacorum have the potential of remediating Arsenicfrom contaminatedwater bodies. The incremental uptake of Arsenic by the two macrophytes with exposure time indicates the sustainability of the remediation process. This is buttressed by the trend seen in Fig. 2 and 3, which shows that the accumulation of Arsenic in the roots still have the potential to absorb more, indicating the possibility of $T$. capensis and $H$. psittacorum in the remediation of Arsenic. These macrophytes represent a reliable alternative for Arsenic remediation in water bodies and soil under climatic conditions of a tropical country like Ghana.

Arsenic is among the toxic and common metal contaminants due to its application in several agrochemicals such as weedicides and pesticides (Rahman et al., 2004; Nachman et al., 2005). Therefore, it remediation is very important inorder to improve agriculture and the quality of water in illicit mining affected communities. The results from this study also had a contrary observation made by Zhou et al. (2009) who reported high concentrations of Arsenic in shoots of $P$. vitaristhan the roots. $H$. psittacorum exhibitedan unusual accumulation trend (Fig. 3). There was limited accumulation rate of arsenic at the initial stages, however, as the exposure time increased, the uptake level also increased.

\section{Effects of Seasonal Variation on Mercury Uptake by T. Capensis and H. Psittacorum}

Mercury uptake by $T$. capensis was the highest among all the heavy metals. There was high Mercury removal in the dry season than the wet season. Statistically, the uptake of mercury differed significantly for dry and wet season, (Table 2-3). The shoots recorded more $\mathrm{Hg}$ than the roots, giving mean $\mathrm{TF}>1$, (Table 4). Mercury removal also increased with exposure time, on the other hand, the wet season recorded less $\mathrm{Hg}$ in the shoots than in the roots. Even though, the wet season recorded lower $\mathrm{Hg}$ levels, the concentration of $\mathrm{Hg}$ in the roots showed increasing removalwith exposure time. In relation to $H$. psittacorum, mercury showed incremental uptake in the dry season. However, the uptake of $\mathrm{Hg}$ in the wet season almost indicated a constant uptake throughout the period of this study. It should be noted that there was no sign of drastic decline with exposure time. For the dry season, the shoots recorded more $\mathrm{Hg}$ than the roots, giving a mean Translocation Factor $>1$ $(1.42 \pm 0.094)$, (Table 5). On the other hand, Translocation Factor $(0.78 \pm 0.038)$ of less than one was recorded for the wet condition. Mercury uptake in both seasons differed significantly (Table 2-5). The occurrence of high $\mathrm{Hg}$ in the shoots of both macrophytes is a function of the Translocation Factor, which shows how readily the macrophytes take up $\mathrm{Hg}$ from soil and water environment. These macrophytes can therefore be used in phytoextraction. Phytoextraction is believed to be the best technology in phytoremediation since it involves the ability of plants to extract contaminant by plants roots and to safely transport it to harvestable parts without any alteration to the soil structure. 
Wiafe Samuel et al. / American Journal of Applied Sciences 2018, 15 (12): 510.518 DOI: 10.3844/ajassp.2018.510.518

Table 2: Independent test statistics for heavy metal uptake by T. capensis and H. psittacorum in the Dry season

\begin{tabular}{|c|c|c|c|c|c|c|}
\hline \multirow{2}{*}{$\begin{array}{l}\text { Heavy Metal } \\
(\mathrm{mg} / \mathrm{kg})\end{array}$} & \multicolumn{2}{|c|}{ Macrophyte root (mean+SD) } & \multicolumn{2}{|c|}{ Macrophyte shoot (mean+SD) } & \multicolumn{2}{|c|}{ Significance (P- value) } \\
\hline & T. capensis & H. Psittacorum & T. capensis & H. Psittacorum & Root & Shoot \\
\hline Arsenic (As) & $62.6 \pm 15.2$ & $49.6 \pm 7.1$ & $29.0 \pm 8.88$ & $50.3 \pm 18.8$ & 1.73 & 0.087 \\
\hline Mercury (Hg) & $88.0 \pm 19.5$ & $35.6 \pm 9.6$ & $101.1 \pm 19.3$ & $50.3 \pm 13.2$ & 0.003 & 0.005 \\
\hline Cadmium (Cd) & $57.9 \pm 40.6$ & $42.6 \pm 7.4$ & $55.1 \pm 22.6$ & $42.6 \pm 7.4$ & 0.487 & 0.334 \\
\hline Lead $(\mathrm{Pb})$ & $101.5 \pm 20.2$ & $62.7 \pm 18.1$ & $116.6 \pm 39.3$ & $69.7 \pm 33.1$ & 0.029 & 0.117 \\
\hline
\end{tabular}

Table 3: Independent test statistics for heavy metal uptake by T. capensis and H. psittacorum in the Wet season

\begin{tabular}{|c|c|c|c|c|c|c|}
\hline \multirow{2}{*}{$\begin{array}{l}\text { Heavy Metal } \\
(\mathrm{mg} / \mathrm{kg})\end{array}$} & \multicolumn{2}{|c|}{ Macrophyte root (mean+SD) } & \multicolumn{2}{|c|}{ Macrophyte shoot (mean+SD) } & \multicolumn{2}{|c|}{ Significance (P- value) } \\
\hline & T. capensis & H. Psittacorum & T. capensis & H. psittacorum & Root & Shoot \\
\hline$\overline{\text { Arsenic (As) }}$ & $41.0 \pm 5.6$ & $42.5 \pm 5.3$ & $12 . \pm 6.3$ & $19.1 \pm 11.2$ & 0.7 & 0.3 \\
\hline Mercury (Hg) & $30.1 \pm 6.3$ & $12.8 \pm 1.9$ & $22.8 \pm 3.8$ & $9.9 \pm 1.1$ & 0.0 & 0.00 \\
\hline Cadmium (Cd) & $57.9 \pm 40.6$ & $37.4 \pm 4.4$ & $25.3 \pm 4.8$ & $12.3 \pm 1.1$ & 0.4 & 0.002 \\
\hline Lead $(\mathrm{Pb})$ & $46.8 \pm 28.1$ & $37 . \pm 29.9$ & $13.4 \pm 1.4$ & $14.2 \pm 1.3$ & 0.6 & 0.439 \\
\hline
\end{tabular}

Table 4: Translocation factor for heavy metal uptake by T. capensis

\begin{tabular}{|c|c|c|c|c|c|c|c|c|}
\hline \multirow{2}{*}{$\begin{array}{l}\text { Translocation } \\
\text { factors }\end{array}$} & \multicolumn{2}{|c|}{ Arsenic } & \multicolumn{2}{|c|}{ Mercury } & \multicolumn{2}{|c|}{ Cadmium } & \multicolumn{2}{|c|}{ Lead } \\
\hline & Dry & Wet & Dry & Wet & Dry & Wet & Dry & Wet \\
\hline$\overline{\text { Day } 10}$ & 0.37 & 0.21 & 1.16 & 0.68 & 0.91 & 0.92 & 0.83 & 0.32 \\
\hline Day 20 & 0.52 & 0.21 & 1.21 & 0.89 & 1.06 & 1.05 & 1.21 & 0.32 \\
\hline Day 30 & 0.46 & 0.28 & 1.16 & 0.78 & 1.24 & 0.27 & 1.17 & 0.41 \\
\hline Day 40 & 0.48 & 0.43 & 1.09 & 0.66 & 1.04 & 0.34 & 1.27 & 0.29 \\
\hline
\end{tabular}

Table 5: Translocation factors of heavy metal uptake by $H$. psittacorum

\begin{tabular}{|c|c|c|c|c|c|c|c|c|}
\hline \multirow{2}{*}{$\begin{array}{l}\text { Translocation } \\
\text { factors }\end{array}$} & \multicolumn{2}{|c|}{ Arsenic } & \multicolumn{2}{|c|}{ Mercury } & \multicolumn{2}{|c|}{ Cadmium } & \multicolumn{2}{|l|}{ Lead } \\
\hline & Dry & Wet & Dry & Wet & Dry & Wet & Dry & Wet \\
\hline Day 10 & 0.53 & 0.22 & 1.53 & 0.83 & 1.04 & 0.32 & 0.61 & 0.63 \\
\hline Day 20 & 0.95 & 0.34 & 1.31 & 0.77 & 1.28 & 0.32 & 1.12 & 0.61 \\
\hline Day 30 & 1.39 & 0.44 & 1.40 & 0.78 & 1.33 & 0.41 & 1.28 & 0.60 \\
\hline Day 40 & 1.22 & 0.77 & 1.47 & 0.74 & 1.08 & 0.29 & 1.18 & 0.19 \\
\hline
\end{tabular}

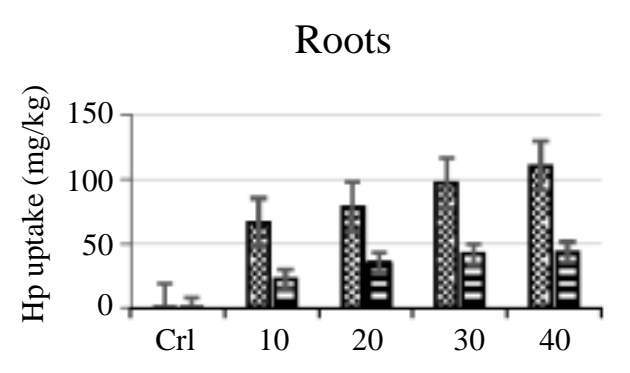

Exposure time (days)

T. capensis
H. psittacorum

\section{Shoots}

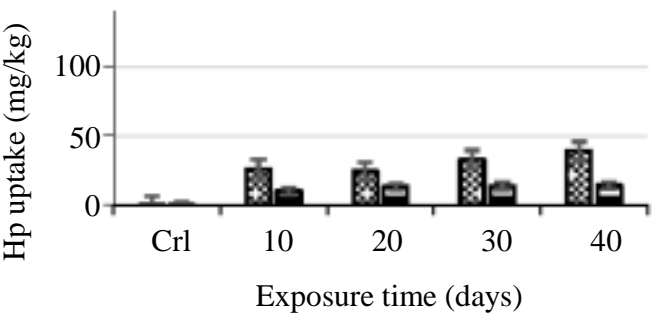

T. capensis $\mathbf{H}$. psittacorum

Fig. 4: Performance of Mercury removal by T. capensis and H. psittacorum in dry conditions

The observation of this study actually confirms this phytoremediation technology. For mercury removal in both seasonal conditions, T. capensis indicated a remarkable $\mathrm{Hg}$ removal than $H$. psittacorum. The rate of
$\mathrm{Hg}$ uptake in $T$. capensis was about twice that of the Heliconia spp for both seasons (Fig. 4 and 5).

Han et al. (2007) conducted a research on the phytoremediation of mercury and reported average 
mercury accumulation in shoots $(10.51 \pm 1.46(\mathrm{mg} / \mathrm{kg}))$ which were higher than root $(6.45 \pm 0.65 \mathrm{mg} / \mathrm{kg})$. The accumulation of mercury reported in this study was in linewith the findings of Han et al. (2007). The incremental uptake of mercury with exposure time indicates the ability of the macrophytes to sustain the remediation process. $T$. capensis is more efficient in $\mathrm{Hg}$ remediation than $H$. psittacorum. The rate of uptake and possible translocation was higher in the dry season than in the wet season.

\section{Effects of Seasonal Variation on Cadmium Uptake by T. Capensis and H. Psittacorum}

The uptake of cadmium was quite slow in the first 10 days but as the exposure time increased, an increment was seen for both seasons. However, the uptake of $\mathrm{Cd}$ in the wet season was more erratic. More $\mathrm{Cd}$ was accumulated in the roots than in the shoots for the wet season given an average translocation factor of $<1$ (0.64 \pm 0.40 - Table 6). Comparatively, in the dry season, there were more $\mathrm{Cd}$ accumulation in the shoots than in the roots. The average translocation factor $(1.06 \pm 0.14-$ Table 4) was thus greater than one. Statistically, Cd uptake by the roots of $T$. capensis did not differ for seasonal conditions but the uptake by the shoots differed significantly (Tables 2-3).

The uptake of cadmium by $H$. psittacorumshowed a constant $\mathrm{Cd}$ uptake for the dry season. In the roots, initially, there were high uptake in the first 10 days but declined slightly to the $20^{\text {th }}$ day before increasing steadily till the 40th day. There were high accumulation in the roots than in the shoots. On the other hand, cadmium uptake by $H$. psittacorum almost showed a constant or stabilized uptake in the dry season. Though there were more accumulation in the roots than the shoots in the dry season. Statistically, Cd uptake by $H$. psittacorum differed significantly for both climate conditions with respect to the shoots and the roots. The dry season had translocation factor $>1 \quad(1.19 \pm 0.14)$ whereas the wet season recorded translocation factor $<1$, (Table 5). Comparatively, T. capensis performed better than $H$. psittacorum in the removal of cadmium with respect to both tissues in the dry season. However, both species showed incremental uptake with regard to exposure time. The continual uptake with exposure time indicates that the macrophyte sustained the remediation process. This is buttressed by the fact that in both species, the highest uptake was obtained on the 40th day harvest, which was the maximum exposure time.

There was also no statistical difference between the $T$. capensis and $H$. psittacorum in terms of Cd uptake in both tissues.

On the other hand, the uptake of cadmium in the wet season conditions did not show the same trend as that which occurred in the dry season, this was more erratic. This observation was slightly different from what happened for $H$. psittacorum. For the roots of psittacorum, there was a slight decline in the removal of $\mathrm{Cd}$ from the first ten days to the 30th day before increasing again on the 40th day. However, with respect to the shoots, both macrophytes behaved in a similar manner. Each recorded the highest accumulation on the 40th day and this shows the sustainability of the remediation process. The high $\mathrm{Cd}$ uptake recorded in the dry season was due to an enhanced transpiration stream. Ekvall and Greger (2003) explained that when plants are grown at higher temperatures, their $\mathrm{Cd}$ translocation increases as a consequence of an enhanced transpiration stream. The results of this study shows that translocation is favored by high temperature (Fig. 5 and 6) which is a characteristic feature of dry season in Ghana. Marschner (1995) reasoned that lower temperature alters the plants membrane fluidity, resulting in lower membrane permeability at low and lower metal uptake.

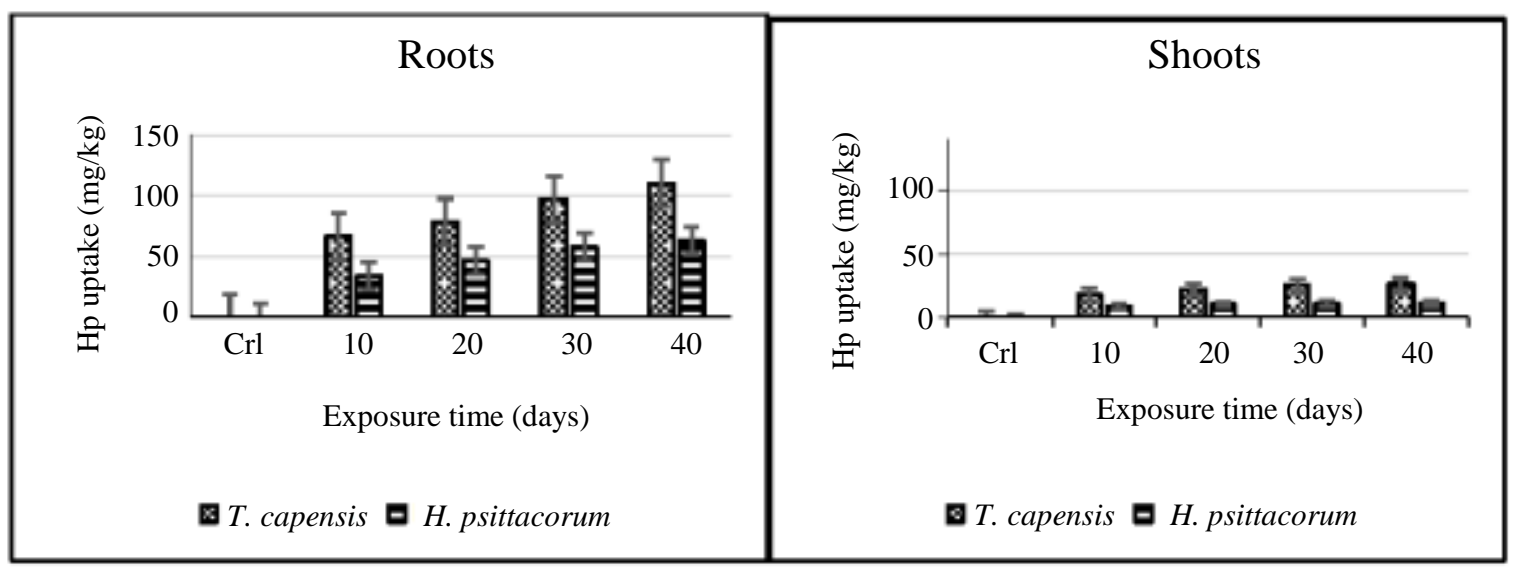

Fig. 5: Performance of mercury removal by $T$. capensis and $H$. psittacorum in dry conditions 
Effects of Seasonal Variation on Lead Uptake by T. Capensis and H. Psittacorum

The remediation of lead by $T$. capensis and $H$. psittacorum are indicated in the Fig. 7 and 8. For $T$. capensis, Lead uptake increased appreciably in both tissues with exposure time. There were more $\mathrm{Pb}$ in the shoots than in the roots for the dry season. However, in the wet season, the roots recorded more $\mathrm{Pb}$ than in the shoots. T. capensis recorded high Translocation factor in the dry season $(1.12 \pm 0.20)$ than in the wet season $(0.33 \pm 0.05)$. Translocation factor greater than one indicates high translocation of $\mathrm{Pb}$ from the roots in to the shoots and this desired of phytoremediants (Kramer, 2000). Pb uptake in the roots and shoots of T. capensis differed significantly for the dry and wet seasons. Lead removal by $H$. psittacorum showed a similar trend to that of $T$. capensis. There was high $\mathrm{Pb}$ uptake in the roots than in the shoots in the dry season, giving a mean translocation factor greater than one $(1.05 \pm 0.3)$. Contrary, the wet season recorded translocation factors $<1(0.51 \pm 0.2)$. The uptake also increased with exposure time in the dry season for both tissues. However, the uptake in the wet season especially, in the shoots was almost stabilized throughout the exposure time. Contrary, the roots recorded a high uptake on the 40th day, though it remained almost constant during the first 30 days. In terms of the dry and wet season, the roots did not show significant difference ( $p>0.05)$ but the shoots showed significant difference $(\mathrm{p}=0.000)$. In other development, there was similar uptake pattern for both macrophytes. With respect to their translocation factors, T. capensis recorded more.

In the dry weather environmental conditions, more $\mathrm{Pb}$ was accumulated in the shoots than in the roots. However, T. capensis removed more $\mathrm{Pb}$ than $H$. psittacorum with respect to roots and shoots. Both macrophytes removed more lead in the roots within the first 10 days than in the shoots. But there was incremental uptake from the 20th harvest to the 40th day harvest. Both plants recorded average translocation factor greater than one in the dry season. Statistically, there was no significant variation in lead removal in the roots and shoots. In relation to the uptake in the wet conditions, there was more $\mathrm{Pb}$ accumulation in the roots than in the shoots throughout the study. The roots showed incremental uptake whereas, the accumulation in the shoots was almost constant throughout the experimental period.

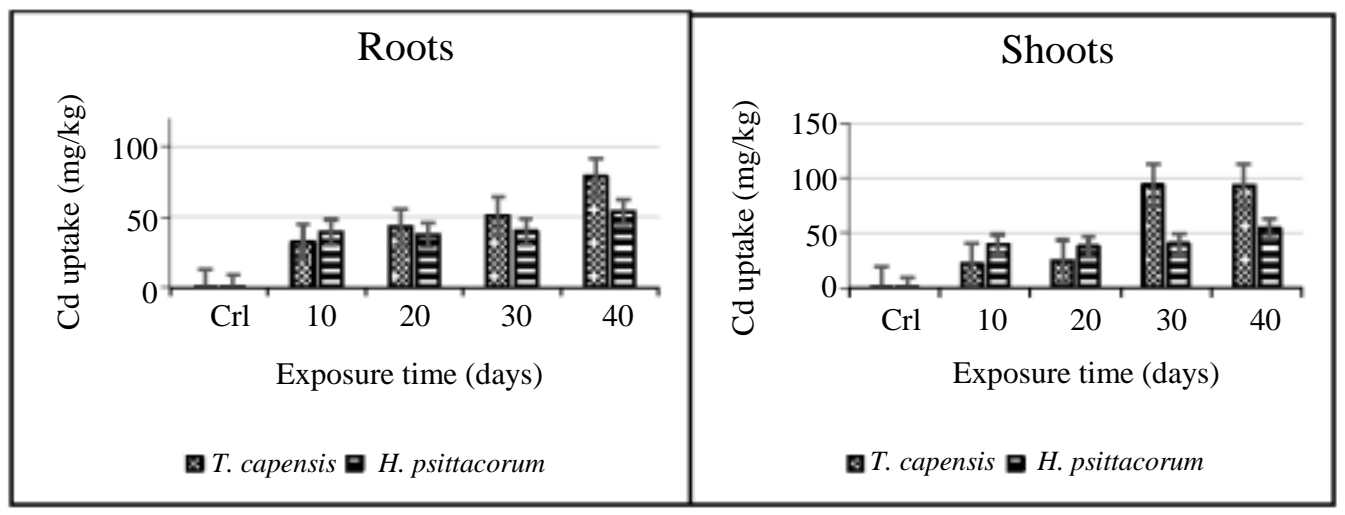

Fig. 6: Performance of cadmium removal by $T$. capensis and H. psittacorum dry conditions

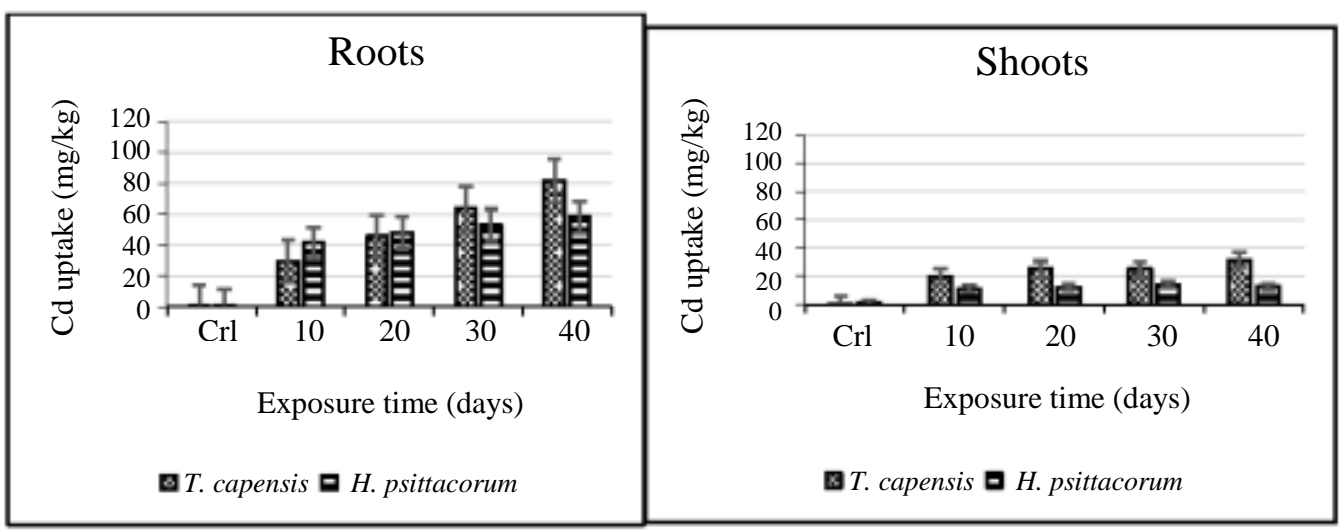

Fig. 7: Performance of cadmium removal by $T$. capensis and $H$. psittacorum 
However, for the wet season, the Heliconia spp was able to remove more $\mathrm{Pb}$ than the Typha spp. This can again be linked to the morphology of the two macrophytes. The broad leaves in the Heliconia enhances transpiration more than capensis. Statistically, there was no significant difference in lead removal in the roots and shoots of these macrophytes $(p>0.05)$. It is also important to note that, the rate of lead uptake in the dry season was about twice of the uptake rate in the wet season for both macrophytes.

\section{Conclusion and Recommendation}

The remediation of the two macrophytes in the uptake of the four selected heavy metals performed better in the dry weather condition than the wet weather condition. The rate of uptake by the $H$. psittacorum is higher in the absorption of arsenic than mercury, cadmium and lead in the dry weather condition. However, in the case of $T$. capensis, the rate of uptake was higher in the absorption of mercury than the arsenic, cadmium and lead in the dry season. Comparatively, the rate of uptake of arsenic by the $H$. psittacorum and $T$. capensis was higher than the rest of the other three metals, however, the levels of arsenic uptake in the $T$. capensiswas higher than $H$. psittacorum. These two macrophytes are rhizomatous in their propagation, so new shoots keeps springing up from their creeping roots which prevents the absorbed heavy metals from leaching back into the soil/water and also, the rate of absorption is enhanced further from the new shoots sprung up.

\section{Acknowledgement}

This study was funded by the Regional Water and Environmental Sanitation Centre, Kumasi (RWESCK) at the Kwame Nkrumah University of Science and Technology, Kumasi with funding from Ghana Government and the World Bank under the Africa Centre's of Excellence project'. The views expressed in this paper do not reflect those of the World Bank, Ghana Government and KNUST.

\section{Author's Contributions}

Samuel Wiafe and Richard Buamah: Carried out the laboratory and field work

Owusu Michael: Conducted the heavy metal Analysis and Data Analysis and the write ups.

\section{Ethics}

All the authors of this research work took of all the ethical obligations in conducting this research and hence no ethical rules were breached.
Consent for Publication: All the authors were unanimous in consenting for the publication of this research paper in this journal.

\section{References}

Albrecht, A., U. Schultze, M. Liedgens, H. Fluhler and E. Frossard, 2002. Incorporating soil structure and root distribution into plant uptake models for radionuclides: Toward a more physically based transfer model. J. Environ. Radioacti., 59: 329-350. DOI: 10.1016/S0265-931X(01)00082-0

Baghour, M., D.A. Moreno, N.J. Herna, N. Castilla and L. Romero, 2001. Influence of root temperature on phytoaccumulation of $\mathrm{As}, \mathrm{Ag}, \mathrm{Cr}$ and $\mathrm{Sb}$ in potato plants (Solanum tuberosum L. var. spunta). J. Environ. Sci. Health A Tox Hazard Subst. Environ. Eng., 36: 1389-1401. DOI: 10.1081/ese-100104886

Boadi, B., D.D. Wemegah and K. Preko, 2013. Geological and structural interpretation of the konongo area of the ashanti gold belt of ghana from aeromagnetic and radiometric data. Int. Res. J. Geology Mining, 3: 124-135.

Forstner, U., 1979. Metal Transfer between Solid and Aqueous Phases. In: Metal Pollution in the Aquatic Environment, Forstner, U. and G.T.W. Wittman (Eds.), Springer-Verlag, Berlin, pp: 197-270.

Hooda, P.S. and B.J. Alloway, 1993. Effects of time and temperature on the bioavailability of $\mathrm{Cd}$ and $\mathrm{Pb}$ from sludge-amended soils. J. Soil Sci., 44: 97-110.13.

Kramer, U. and A.N. Chardonnens, 2000. The use of transgenic plants in the bioremediation of soils contaminated with trace elements. Appl. Microbiol. Biotechnol., 55: 661-672.

Lynch, D.V. and P.L. Steponkus, 1987. Plasma membrane lipid alterations associated with cold acclimation of winter rye seedlings (Secalecereale L. CV Puma). Plant Physiol., 83: 761-767.

Macek, T., P. Kotrba, M. Suchova, F. Skacel and K. Demnerova et al., 1994. Accumulation of cadmium by hairy-root cultures of Solanum nigrum. Biotechnol. Letters, 16: 621-624.

Marschner, H., 1995. Mineral Nutrition of Higher Plants. Academic Press Limited, London.

Nachman, K.E., J.P. Graham, L.B. Price and E.K. Silbergeld, 2005. Arsenic: A roadblock to potential animal waste management solutions. Environ. Health Perspect, 113: 1123-1124.

Rahman, F.A., D.L. Allan, C.J. Rosen and M.J. Sadowsky, 2004. Arsenic availability from chromated copper arsenate (CCA)-treated wood. J. Environ. Qual., 33: 173-180.

Rooney, N. and J. Kalff, 2000. Inter-annual variation in submerged macrophyte community biomass and distribution: The influence of temperature and Lake Morphometry. Aquatic Botany, 68: 321-335. 
Wiafe Samuel et al. / American Journal of Applied Sciences 2018, 15 (12): 510.518 DOI: 10.3844/ajassp.2018.510.518

Zhou, Q., J. Zhang, J. Fu, J. Shi and G. Jiang, 2009. Biomonitoring: An appealing tool for assessment of metal pollution in the aquatic ecosystem. Anal. Chim. Acta, 606: 135-150.
Zumdahl, S.S., 1992. Chemical Principles. D.C. Heath and Company, Canada. 